\title{
Ekspresi Protein $B-R A F$ Mutan pada Karsinoma Tiroid Papilifer yang Bermetastasis ke Kelenjar Getah Bening Regional
}

\author{
Dimyati Achmad, Jeremy Sebastian, Bethy S. Hernowo, Kiki A. Rizki \\ Divisi Bedah Onkologi, Kepala dan Leher, Departemen Ilmu Bedah Fakultas Kedokteran \\ Universitas Padjadjaran Rumah Sakit Dr. Hasan Sadikin Bandung
}

\begin{abstract}
Abstrak
Karsinoma tiroid papilifer (KTP) dapat tumbuh progresif dan sekitar 33-61\% kasus secara klinis telah metastasis ke kelenjar getah bening (KGB) regional pada saat diagnosis ditegakkan. Mutasi gen $B-R A F$ dihubungkan dengan sifat biologis progresivitas KTP. Mutasi gen $B-R A F$ akan mengkode protein B-RAF mutan yang bertindak sebagai regulator sentral pada jalur mytogen activated-pathway kinase (MAPK) dalam proses proliferasi dan dediferensiasi. Mutasi gen $B-R A F$ dapat diidentifikasi pada tingkat deoxyribosenucleic acid (DNA), ribonucleic acid (RNA), dan protein. Masih terdapat kontroversi antara hubungan mutasi $B-R A F$ dan metastasis KGB regional. Tujuan penelitian ini untuk mengetahui hubungan protein B-RAF mutan dengan metastasis ke KGB regional pada KTP. Penelitian ini merupakan penelitian observasional rancangan kuantitatif, studi kasus kontrol berpasangan. Penelitian dilakukan di Subbagian Bedah Onkologi, Kepala dan Leher, Departemen Ilmu Bedah dan Patologi Anatomi Fakultas Kedokteran Universitas Padjadjaran/Rumah Sakit Dr. Hasan Sadikin Bandung. Sampel penelitian terdiri atas 38 kasus KTP dengan metastasis dan 38 kasus kontrol tanpa metastasis ke KGB regional yang dirawat di Rumah Sakit Dr. Hasan Sadikin Bandung pada periode Januari 2003-Desember 2010 dan dipilih berdasarkan proses matching. Masing-masing kelompok diperiksa B-RAF mutan dengan metode imunohistokimia. Hubungan antara tiap variabel bebas dan variabel tergantung diuji menggunakan analisis bivariat Uji McNemar. Hasil penelitian menunjukkan protein B-RAF mutan memiliki hubungan bermakna $(p=0,023)$ dengan metastasis ke KGB regional pada KTP. Terdapat protein B-RAF mutan pada KTP mempunyai risiko untuk metastasis ke KGB regional sebesar 5,92 kali dibandingkan dengan tanpa mutasi $B-R A F$. Penelitian ini juga menunjukkan prevalensi B-RAF mutan sebesar 65,8\% (32 kelompok kasus dan 18 kelompok kontrol). Simpulan, protein B-RAF mutan memiliki hubungan dengan metastasis ke KGB regional pada KTP. [MKB. 2013;45(4):245-50]
\end{abstract}

Kata kunci: Imunohistokimia, karsinoma tiroid papilifer, metastasis ke KGB regional, mutasi $B-R A F$

\section{Mutant B-RAF Protein Expression in Regional Lymph Node Metastasized Papillary Thyroid Carcinoma}

\begin{abstract}
s
Papillary thyroid carcinoma (PTC) can become progressive and in about $33-61 \%$ of cases it has metastasized to regional lymph nodes at diagnosis. Mutation of B-RAF gene correlated with the biological characteristic of lymph node progressivity. Mutation of B-RAF will encode mutant B-RAF protein which acts as the central regulator on mytogen activated-pathway kinase (MAPK) pathway in terms of proliferation and dedifferentiation processes. B-RAF gene mutation can be identified at deoxyribosenucleic acid (DNA), ribonucleic acid (RNA) and protein levels. There are still controversies in corelation between B-RAF mutation and regional lymph node metastasis. The purpose of this study was to discover the correlation between mutant B-RAF protein and regional lymph node metastasis on PTC. This is a quantitative observational paired case-control study. The study was conducted at the Surgical Oncology, Head and Neck Division Departement of Surgery and Pathology Anatomy Departement, Faculty of Medicine, Universitas Padjadjaran/Dr. Hasan Sadikin General Hospital Bandung in April 2011-January 2012. The sample consisted of 38 PTC cases with metastasis and 38 control cases without regional lymph node metastasis treated in Dr. Hasan Sadikin Hospital between January 2003-December 2010 which have been selected based on the matching process. Each group was examined using the immunohistochemistry method. Correlation between each dependent and non-dependent variables were tested using McNemar bivariate analysis. The results showed that mutant B-RAF protein have a significant correlation $(\mathrm{p}=0.023)$ with lymph node metastasis in PTC. The risk of metastasis in B-RAF mutant group was 5.92 times higher than without mutation. This study also showed that from 76 PTC cases studied, the prevalence of mutant B-RAF was about $65.8 \%$ (32 in cases and 18 in control group). In conclusion, there is a correlation between mutant B-RAF protein and regional lymph node metastasis in papillary thyroid carcinoma. [MKB. 2013;45(4):245-50]
\end{abstract}

Key words: $B-R A F$ mutation, immunohystochemistry, papillary thyroid carcinoma, regional lymph node metastasis

Korespondensi: Dr. Dimyati Achmad, dr., Sp.B(K) Onk, Departemen Ilmu Bedah Fakultas Kedokteran Universitas Padjadjaran Rumah Sakit Dr. Hasan Sadikin Bandung, mobile 085624235051 e-mail jerss82@hotmail.com 


\section{Pendahuluan}

Karsinoma tiroid merupakan karsinoma sistem endokrin yang paling sering ditemukan. Terdapat 33.500 kasus baru karsinoma tiroid pada tahun 2007 di Amerika Serikat, 1k. 90\% merupakan kasus karsinoma tiroid berdiferensiasi baik. ${ }^{1,2}$ Berdasarkan data yang dilaporkan dari Badan Registrasi Kanker Indonesia pada tahun 1998, karsinoma tiroid merupakan karsinoma pada urutan ke-9 dari seluruh kejadian karsinoma. ${ }^{3}$

Karsinoma tiroid dibedakan atas tiga tingkat diferensiasi yaitu diferensiasi baik, intermediate, dan buruk. ${ }^{3}$ Karsinoma tiroid diferensiasi baik terdiri atas karsinoma tiroid papilifer (KTP), folikuler (KTF), dan juga sel Hürthle. Karsinoma tiroid papilifer merupakan tipe histopatologi karsinoma tiroid yang menjadi perhatian para peneliti karena insidensinya yang tinggi yaitu 80 $85 \%$ dari kasus karsinoma tiroid dan diagnosis dapat ditegakkan dengan pemeriksaan sitologi melalui tindakan biopsi jarum halus. Karsinoma tiroid papilifer memiliki sifat biologis yang mirip lesi jinak dengan tingkat pertumbuhan yang lambat sehingga sering disebut sebagai benign carcinoma. . $^{3-5}$

Meskipun memiliki sifat biologis yang mirip lesi jinak dan dengan angka harapan hidup 20 tahun dapat mencapai $90 \%$, tetapi KTP dapat tumbuh secara progresif dan 33-61\% kasus secara klinis telah mengadakan metastasis ke kelenjar getah bening (KGB) regional pada saat diagnosis ditegakkan. ${ }^{3}$ Metastasis ke KGB regional tidak berhubungan langsung dengan memburuknya prognosis tetapi dihubungkan dengan peningkatan rekurensi setelah tindakan definitif, baik lokal maupun lokoregional. Terdapat hubungan jumlah KGB regional yang terlibat metastasis dengan rekurensi, dan kejadian rekurensi akan semakin tinggi bila pada KGB terdapat invasi sel KTP melewati kapsul. ${ }^{6}$ Tang dan Lee $^{7}$ melaporkan angka harapan hidup 10 tahun penderita KTP mencapai lebih dari $90 \%$, namun sampai $35 \%$ penderita mengalami rekurensi selama kurun waktu 40 tahun follow up.

Beberapa faktor risiko memiliki peran penting dalam prognosis KTP antara lain usia, grading tumor, invasi ekstratiroid, ukuran tumor, dan faktor genetik. Beberapa molekul genetik dilaporkan dapat digunakan sebagai petanda prediktor KTP. Gen yang berperan dalam mengkode protein pada jalur mitogen-activated protein kinase (MAPK) telah banyak dipelajari, dan mutasi salah satu gen tersebut yaitu $B-R A F$, dilaporkan terjadi pada KTP yang mengalami ekstensi ekstratiroid, metastasis KGB, dan rekurensi. ${ }^{3}$ Mutasi gen $B-R A F$ dihubungkan dengan sifat biologis KTP yang progresif, dengan prevalensi yang tinggi dijumpai pada usia dewasa dan lanjut, namun tidak berhubungan dengan faktor risiko radiasi. Sampai saat ini mekanisme molekuler yang pasti mengenai peran mutasi $B-R A F$ dalam metastasis ke KGB regional pada KTP masih belum jelas. ${ }^{3}$ Mutasi famili gen $R A F$ yang terbanyak ditemukan pada KTP adalah mutasi gen $B-R A F$ pada poin T 1799 A dari ekson 15 yang mengkode protein B-RAF mutan. Protein B-RAF mutan itu akan bertindak sebagai regulator sentral jalur MAPK dalam hubungannya dengan proses proliferasi dan juga dediferensiasi. ${ }^{8-11}$ Mutasi $B-R A F$ itu dapat diidentifikasi pada tingkat deoxyribonucleic acid (DNA) melalui pemeriksaan polymerase chain reaction (PCR), tingkat ribonucleic acid (RNA) dengan pemeriksaan reverse transcription polymerasechain reaction (RT-PCR), dan tingkat protein melalui pemeriksaan imunohistokimia. Polymerase chain reaction (PCR) merupakan pemeriksaan utama dalam identifikasi mutasi $B-R A F$, namun teknik prosedur yang kompleks dan biaya yang mahal menjadi keterbatasan pada pemeriksaan ini. Pemeriksaan imunohistokimia banyak menjadi pilihan para peneliti karena pemeriksaan dapat dilakukan lebih cepat, relatif tidak mahal, tidak diperlukan ekstraksi DNA, dan dapat memeriksa langsung pada tingkat protein produk gen-terkait-tumor. ${ }^{12}$

Hasil penelitian secara retrospektif pada KTP, mendapatkan hubungan positif mutasi $B-R A F$ yang diidentifikasi pada tingkat DNA dengan invasi secara ekstratiroid dan metastasis ke KGB regional..$^{11,13,14}$ Lupi dkk. ${ }^{15}$ melakukan penelitian pada tingkat DNA secara retrospektif pada 500 kasus KTP dan mendapatkan bahwa 43,8\% kasus terdeteksi mutasi $B-R A F$ dan dilaporkan pula bahwa mutasi $B-R A F$ tersebut berhubungan yang bermakna dengan invasi secara ekstratiroid dan metastasis ke KGB regional. Kemampuan invasi itu secara ekstratiroid didukung dengan penelitian yang berhubungan kemampuan sel KTP melakukan migrasi. Kemampuan migrasi dihubungkan dengan ekspresi protein Met yang meningkat dan merupakan protein reseptor di membran sel KTP yang akan berikatan dengan hepatocyte growth factor (HGF) menghasilkan sinyal tirosin kinase yang berhubungan dengan rangsangan migrasi dan invasi. ${ }^{15,16}$

Penelitian lain yang dilakukan oleh Fugazzola dkk..${ }^{17}$ Chung dkk., ${ }^{18}$ dan Ito dkk..${ }^{19}$ mendapatkan hasil berbeda, bahwa tidak terdapat hubungan antara mutasi $B-R A F$ dan progresivitas KTP termasuk metastasis ke KGB regional. Keadaan yang sama dilaporkan oleh Durante dkk. ${ }^{20}$ dari penelitian mutasi $B-R A F$ yang diidentifikasi pada tingkat RNA.

Terdapat kontroversi mengenai peran mutasi $B-R A F$ terhadap metastasis ke KGB regional 
pada KTP dan diketahuinya peran protein B-RAF mutan sebagai regulator sentral pada jalur MAPK membuat penulis tertarik melakukan penelitian pada tingkat protein mengenai hubungan protein B-RAF mutan dengan metastasis ke KGB regional pada KTP.

\section{Metode}

Penelitian ini merupakan penelitian observasional dengan mempergunakan rancangan kuantitatif studi kasus kontrol. Subjek penelitian ini adalah penderita KTP yang dirawat di Rumah Sakit Dr. Hasan Sadikin (RSHS) Bandung periode Januari 2003 hingga Desember 2010 dan didiagnosis secara klinis serta histopatologi dengan dan tanpa metastasis ke KGB regional dan varian histopatologi merupakan varian klasik. Kriteria eksklusi terdapat riwayat paparan radiasi, catatan rekam medik tidak lengkap, blok parafin rusak, dan varian histopatologi adalah varian tall cell, diffuse sclerosing, columnar cell, atau folikuler.

Dengan mempergunakan rumus penentuan besaran sampel yang minimal penelitian analitik kategorik berpasangan dalam studi kasus kontrol, didapatkan besar sampel minimal untuk kelompok kasus dan kontrol masing-masing 38 kasus. Penilaian protein $B-R A F$ mutan itu berdasarkan analisis pemeriksaan imunohistokimia (IHC) yang terdiri atas dua nilai yaitu nilai positivitas merupakan penghitungan kualitatif, dan nilai distribusi positivitas dalam bentuk penghitungan kuantitatif sehingga pemeriksaan ini bersifat semikuantitatif. Nilai positivitas intensitas ditambah angka satu dikalikan dengan nilai positivitas distribusi $(\mathrm{HS}=[\mathrm{i}+1] \mathrm{xd})$ kemudian ditentukan cut-off point pada nilai 4 sehingga didapat nilai positif untuk angka $\geq 4$ dan nilai negatif untuk angka $<4$. Analisis IHC dilakukan oleh dua orang ahli patologi anatomi yang memiliki kompetensi dalam pemeriksaan IHC. Pemeriksaan KTP dengan metastasis ke KGB regional adalah KTP yang secara klinis dan histopatologi ditemukan pembesaran KGB regional.

Data yang dipergunakan berupa catatan/rekam medik untuk mengindentifikasi semua penderita KTP yang memenuhi kriteria inklusi. Diambil data mengenai usia saat diagnosis ditegakkan dan data mengenai ada atau tidaknya metastasis ke KGB regional. Blok parafin dikumpulkan, dipotong, dan kemudian dilakukan deparafinisasi dengan xilen dan direhidrasi melalui serial larutan alkohol bergradasi diikuti dengan nuclease free water dan peroksidase endogen dimatikan $\left(\mathrm{H}_{2} \mathrm{O}_{2}\right.$ $3 \%$, selama 30 menit, temperatur ruangan). Untuk menentukan ekspresi B-RAF mutan digunakan antibodi Rabbit monoclonal (EP 152 Y) ab33899 dari Abcam, United Kingdom.

Hasil pemeriksaan variabel bebas dalam skala pengukuran semikuantitatif dikategorikan dalam bentuk skala nominal dikotom dan berdasarkan
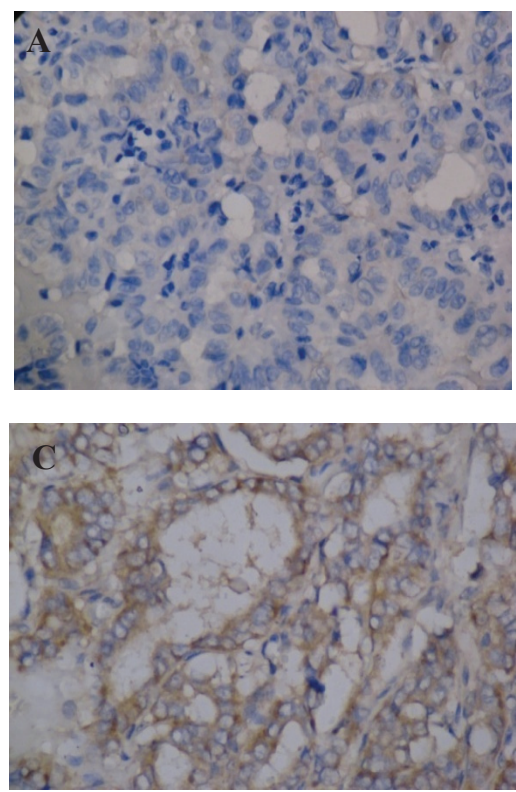
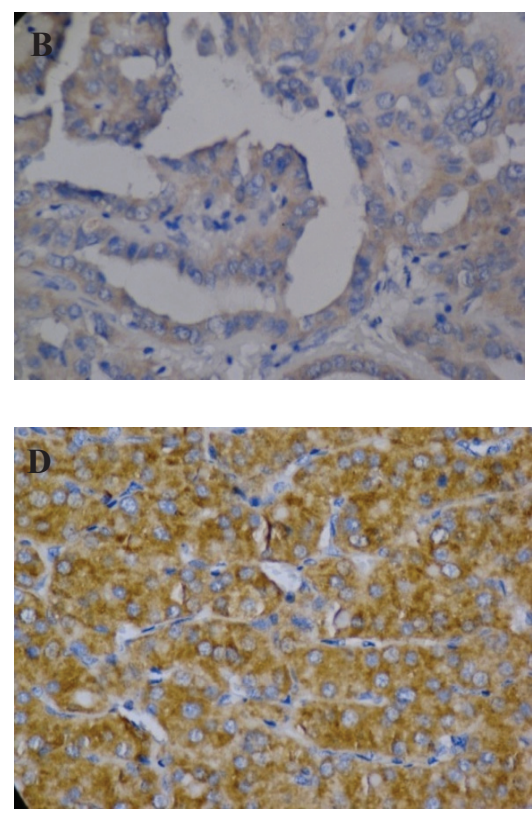

\section{Gambar Intensitas Warna IH B-RAF}

(A) Intensitas warna IHC B-RAF negatif, (B) Intensitas warna IHC B-RAF positif lemah, (C) Intensitas warna IHC B-RAF positif sedang, (D) Intensitas warna IHC B-RAF positif kuat 
Tabel 1 Karakteristik Usia pada Kedua Kelompok Penelitian

\begin{tabular}{|c|c|c|c|}
\hline \multirow[b]{2}{*}{ Usia (tahun) } & \multicolumn{2}{|c|}{ Kelompok } & \multirow[b]{2}{*}{$\mathbf{p}$} \\
\hline & $\begin{array}{c}\text { Kasus } \\
(\mathbf{n}=\mathbf{3 8})\end{array}$ & $\begin{array}{c}\text { Kontrol } \\
(\mathrm{n}=38)\end{array}$ & \\
\hline$<30$ & 6 & 6 & \\
\hline $30-39$ & 4 & 5 & \\
\hline $40-49$ & 7 & 6 & \\
\hline $50-59$ & 6 & 6 & \\
\hline $60+$ & 15 & 15 & \\
\hline Rata-rata (SD) & $51,0(17,8)$ & $49,0(17,3)$ & 0,626 \\
\hline Median & 52,5 & 51,5 & \\
\hline Rentang & $18-80$ & $17-74$ & \\
\hline
\end{tabular}

Keterangan: $\mathrm{p}$ dihitung berdasarkan uji-t

nilai cut-off point pada angka 4. Variabel bebas dikomparasi dengan variabel tergantung yang juga dalam bentuk skala nominal dikotom dengan menggunakan Uji McNemar dengan interpretasi berdasarkan nilai $\mathrm{p}<0,05$.

Penelitian ini dilaksanakan di Divisi Bedah Onkologi, Kepala dan Leher, dari Departemen Ilmu Bedah Fakultas Kedokteran Universitas Padjadjaran dan Departemen Patologi Anatomi Fakultas Kedokteran Universitas Padjadjaran/ RSHS Bandung. Waktu penelitian dari April 2011 sampai Januari 2012.

Penelitian ini menggunakan objek penelitian berupa blok parafin dari penderita KTP dengan atau tanpa disertai metastasis ke KGB regional. Walaupun tidak berhubungan langsung dengan penderita tetapi penelitian ini mempergunakan jaringan yang berasal dari sel tubuh penderita. Penelitian ini dilaksanakan setelah memperoleh persetujuan dari Departemen Patologi Anatomi Fakultas Kedokteran Universitas Padjadjaran/ RSHS Bandung dan rekomendasi dari Komite Etik Penelitian Kesehatan Fakultas Kedokteran Universitas Padjadjaran/RSHS Bandung, Nomor LB.04.01/A05/EC/008/II/2013.

\section{Hasil}

Penelitian tentang hubungan protein B-RAF mutan dengan metastasis ke KGB regional telah dilakukan terhadap 38 kasus KTP metastasis ke KGB regional dan 38 kasus KTP tanpa metastasis ke KGB regional sebagai kontrol yang dipilih berdasarkan proses matching dari penderita KTP yang dirawat di RSHS Bandung pada periode Januari 2003 sampai Desember 2010.

Gambaran karakteristik kedua kelompok itu berdasarkan usia tidak menunjukkan perbedaan
Tabel 2 Hasil Pemeriksaan Protein B-RAF Mutan

\begin{tabular}{lccc}
\hline \multirow{2}{*}{$\begin{array}{c}\text { B-RAF } \\
\text { Mutan }\end{array}$} & \multicolumn{2}{c}{ Kelompok } & p \\
\cline { 2 - 3 } & $\begin{array}{c}\text { Kasus } \\
(\mathbf{n = 3 8 )}\end{array}$ & $\begin{array}{c}\text { Kontrol } \\
(\mathbf{n}=\mathbf{3 8})\end{array}$ & \\
\hline Positif & 32 & 18 & 0,023 \\
Negatif & 6 & 20 & \\
\hline
\end{tabular}

Keterangan: Nilai p dihitung berdasarkan Uji McNemar. OR: 5,92 (95\% IK:2,01-17,45)

yang bermakna ( $\mathrm{p}>0,05)$, sehingga layak dapat dibandingkan (Tabel 1).

Protein B-RAF mutan memiliki hubungan bermakna $(\mathrm{p}=0,023)$ dengan terjadinya metastasis ke KGB regional pada KTP; terdapat protein B-RAF mutan pada KTP mempunyai risiko untuk terjadi metastasis ke KGB regional sebesar 5,92 kali bila dibandingkan dengan tanpa B-RAF mutan (Tabel 2).

\section{Pembahasan}

Dari 76 kasus KTP yang diteliti, prevalensi B-RAF mutan sebesar $65,8 \%$ (32 kelompok kasus dan 18 kelompok kontrol). Prevalensi B-RAF mutan yang diidentifikasi dengan IHC, tidak berbeda dengan hasil yang dilaporkan Xing ${ }^{10}$ dari laporan beberapa pustaka, mendapatkan prevalensi mutasi $B-R A F$ yang diidentifikasi pada tingkat DNA dan RNA yaitu sebesar 28-83\%. Cohen dkk. ${ }^{9}$ mendapatkan prevalensi mutasi $B-R A F$ yang diperiksa pada tingkat DNA sebesar $67 \%$. Bila dibandingkan dengan hasil penelitian Cohen dkk. ${ }^{9}$ hasil penelitian ini ternyata tidak berbeda, walaupun metode pemeriksaan ketiga 
penelitian tidak sama.

Identifikasi protein B-RAF mutan pada penelitian ini berdasarkan peran protein tersebut sebagai regulator sentral dalam jalur MAPK. Mutasi genetik $B-R A F$ yang terjadi dalam metastasis ke KGB akan mengkode protein B-RAF mutan. ${ }^{9}$ B-RAF mutan akan mengaktifkan protein MEK pada jalur MAPK yang selanjutnya akan menyebabkan fosforilasi ERK sehingga terbentuk protein ERK aktif. Protein ini akan masuk ke dalam inti sel untuk menginduksi faktor transkripsi di antaranya c-jun, c-fos, dan c-met. Rangsangan pada c-jun, c-fos akan menyebabkan sel KTP aktif berproliferasi, dediferensiasi, dan bertahan hidup. ${ }^{9}$ Transkripsi gen $c$-met akan mengekspresikan protein Met sebagai reseptor tirosin kinase yang selanjutnya akan diaktivasi oleh HGF, sehingga sel KTP mampu bermigrasi menembus kapsul tumor primer tersebut dan dapat menginvasi kapsul tiroid masuk ke struktur ekstratiroid dan menginvasi struktur limfatik di luar tiroid. ${ }^{16-18}$

Identifikasi protein B-RAF mutan itu dapat dijadikan salah satu pemeriksaan penunjang pada penderita KTP untuk mengetahui kemungkinan terjadi metastasis ke KGB regional. Dibandingkan dengan metode identifikasi mutasi $B-R A F$ lainnya (PCR dan RT-PCR), metode IHC mempunyai beberapa keunggulan antara lain relatif lebih cepat, tidak mahal, dan tidak diperlukan ekstraksi DNA. ${ }^{12}$ Informasi protein B-RAF mutan pada penderita KTP dapat menjadi salah satu faktor untuk menentukan jenis tindakan operasi.

Penelitian ini adalah penelitian retrospektif, menggunakan data rekam medik dan blok parafin yang berasal dari data rekam medik. Sering kali data dari satu sumber tidak lengkap, sehingga untuk mengantisipasi keadaan ini dilakukan penelusuran data yang berjenjang. Mulai dari data operasi yang tercatat direkam kegiatan operasi di Divisi Bedah Onkologi Kepala dan Leher Departemen Ilmu Bedah Fakultas Kedokteran Universitas Padjadjaran/RSHS Bandung. Data kemudian dicek ulang dengan data yang ada di Ruang Rawat Inap RSHS Bandung. Setelah itu dicari buku rekam medik di Divisi Rekam Medik RSHS Bandung. Terdapat beberapa data yang tidak sesuai antara sumber satu dan lainnya serta terdapat beberapa rekam medik yang tidak dicatat dengan lengkap serta terdapat beberapa rekam medik yang tidak dapat ditemukan arsipnya. Untuk mendapatkan jumlah kasus yang sesuai dengan jumlah sampel penelitian maka dilakukan penelurusan data selama periode yang cukup panjang yaitu dari tahun 2003 sampai dengan 2010, kemudian dicari blok parafin yang sesuai, yang tersimpan di Departemen Patologi Anatomi Fakultas Kedokteran Universitas Padjadjaran/
RSHS Bandung.

Simpulan, protein B-RAF mutan mempunyai hubungan dengan metastasis ke KGB regional pada KTP.

\section{Daftar Pustaka}

1. Jemal A, Siegal R, Xu J, Ward E. Cancer Statistics, 2010. CA Cancer J Clin. 2010;60(5):277-300.

2. Davies L, Welch HG. Increasing incidence of thyroid cancer in the united state, 1973-2002. JAMA. 2006; 295(18):2164-7.

3. Badan Registrasi Kanker. Jakarta 1998: Ikatan Ahli Patologi Indonesia - Departemen Kesehatan Republik Indonesia; 1998.

4. Carling $\mathrm{T}$, Udelsman R. Thyroid tumors. Dalam: DeVita VT Jr, Lawrence TS, Rosenberg SA, penyunting. DeVita, Hellman and Rosenberg's cancer principles and practice of oncology. Edisi ke-8. Philadelphia: Lippincott Williams and Wilkins; 2008. hlm. 1663-90.

5. Masjhur JS. Kontroversi dalam pengelolaan karsinoma tiroid berdiferensiasi. Simposium Endokrinologi Klinik; 2007.

6. Leboulleux S, Rubino C, Baudin E, Caillou B, Hartl DM, Bidart JM, dkk. Prognostic factors for persistent or recurrent disease of papillary thyroid carcinoma with neck lymph node metastases and/or tumor extension beyond the thyroid capsule at initial diagnosis. J Clin Endocrinol Metab. 2005;90(10):5723-9.

7. Tang KT, Lee CH. BRAF mutation in papillary thyroid carcinoma: pathogenic role and clinical implications. J Chin Med Assoc. 2010;73(3):113-28.

8. Mitsutake N, Miyagishi M, Mitsutake S, Akeno N, Mesa C Jr, Knauf JA, dkk. BRAF mediates RET/PTC-induced mitogenactivated protein kinase activation in thyroid cells: functional support for requirement of the RET/PTC-RAS-BRAF pathway in papillary thyroid carcinogenesis. Endocrinology. 2006;147(2):1014-9.

9. Cohen Y, Xing M, Mambo E, Guo Z, Wu G, Trink B, dkk. BRAF mutation in papillary thyroid carcinoma. J Natl Cancer Inst. 2004;95(8):625-7.

10. Xing M. BRAF mutation in thyroid cancer. Endoc Relat Cancer. 2005;12(2):245-62.

11. Kim KH, Kang DW, Kim SH, Seong IO, Kang DY. Mutations of the BRAF gene in papillary thyroid carcinoma in a Korean population. Yonsei Med J. 2004;45(5):818-21.

12. Capper D, Weissert S, Balss J, Habel A, Meyer J, Jager D, dkk. Characterization of 
R132H mutation-specific IDH1 antibody binding in brain tumors. Brain Pathol. 2010;20(1):245-54.

13. Nikiforova MN, Kimura ET, Gandhi M, Biddinger PW, Knauf JA, Basolo F, dkk. BRAF mutations in thyroid tumors are restricted to papillary carcinomas and anaplastic or poorly differentiated carcinomas arising from papillary carcinomas. J Clin Endocrinol Metab. 2003;88(11):5399-404.

14. Riesco-Eizaguirre G, Gutierrez-Martinez P, Garcia-Cabezas MA, Nistal M, Santisteban $\mathrm{P}$. The oncogene BRAF V600E is associated with a high risk of recurrence and less differentiated papillary thyroid carcinoma due to the impairment of $\mathrm{Na}+/ \mathrm{I}-$ targeting to membrane. Endocr Relat Cancer. 2006;13(1):257-69.

15. Lupi C, Giannini R, Ugolini C, Proietti A, Berti P, Minuto M, dkk. Extensive clinical experiences. Association of BRAF V600E mutation with poor clinicopathological outcomes in 500 consecutive cases of papillary thyroid carcinoma. J Clin Endocrinol Metab. 2007;92(11):4085-90.

16. Mineo R, Constantino A, Frasca F, Sciacca L, Russo S, Vigneri R, dkk. Activation of the hepatocyte growth factor (HGF)-Met system in papillary thyroid cancer: biological effects of HGF in thyroid cancer cells depend on Met expression levels. Endocrinology. 2004;145(9):4355-65.

17. Fugazzola L, Mannavola D, Cirello V, Vannucchi G, Muzza M, Vicentini L dkk. BRAF mutations in an Italian cohort of thyroid cancers. Clin Endocrinol. 2004;61(2):23943.

18. Chung KW, Yang SK, Lee GK, Kim Ey, Kwon S, Lee SH, dkk. Detection of BRAFV600E mutation on fine needle aspiration specimens of thyroid nodules refines cyto-pathology diagnosis, especially in BRAF600E mutation-prevalent area. Clin Endocrinol. 2006;65(5):660-6.

19. Ito Y, Yoshida H, Maruo R, Morita S, Takano $\mathrm{T}$, Hirokawa M, dkk. BRAF mutation in papillary thyroid carcinoma in a Japanese population: its lack of correlation with high-risk clinicopathological features and disease-free survival of patients. Endoc J. 2009;56(1):89-97.

20. Durante C, Puxeddu E, Ferretti E, Morisi R, Moretti S, Bruno R, dkk. BRAF mutations in papillary thyroid carcinomas inhibit genes involved in iodine metabolism. J Clin Endocrinol Metab. 2007;92(7):2840-3. 